Original Research Paper

\title{
Uncertainty Analysis of Time of Concentration Equations based on First-Order-Analysis (FOA) Method
}

\author{
Asghar Azizian \\ Department of Water Engineering, \\ Faculty of Engineering and Technology, Imam Khomeini International University, Qazvin, Iran
}

Article history

Received: 10-02-2018

Revised: $12-02-2018$

Accepted: 19-03-2018

Email: Azizian@eng.ikiu.ac.ir

\begin{abstract}
The time of concentration $(T c)$ is one the most important time parameters to predict the response of a catchment to a given rainfall and plays a key role in the hydrologic design and rainfall-runoff modeling. There are a huge number of empirical/semi-empirical equations for estimation of $T_{c}$ and depending on several parameters such as rainfall attributes, topographic and land cover map scale, DEM resolution and streams delineation threshold causes significant uncertainties in the $T_{c}$ value. How to quantitatively evaluate the uncertainties in model parameters and the resulting uncertainty impacts on model outputs has always been a question which has attracted much attention. In this study, the method based on the First-Order-Analysis (FOA) is used to analyze the uncertainty and the contribution of each parameter on the output of $47 T_{c}$ formulas in Kasilian and Amameh watersheds. The results show that among the $47 T_{c}$ equations, equations which are based on watershed's characteristics, rainfall attributes and land cover-related coefficients such as Overton-Meadows, ASCE, Akan, Kinematic-Wave, McCuen et al. and Izzard have relatively high uncertainty and the average CV of these equations is about $45 \%$. In addition, equations that are based on only geomorphological parameters have relatively low uncertainty (the average CV is about $16 \%$ ). Further analysis of the effects of parameter uncertainties on the $T_{c}$ equations reveals that the uncertainty associated with rainfall attributes and land cover-related coefficients have great impacts on results of the $T_{c}$ equations and the uncertainty caused by these factors in humid regions relative to dry/ semi dry regions is different. Moreover, in the geomorphological-based equations, the uncertainty caused by streams delineation threshold is approximately 3-6 times of scale effects' uncertainty.
\end{abstract}

Keywords: Time of Concentration, Uncertainty Analysis, First Order Analysis, Scale Effects

\section{Introduction}

Most of the hydrological analyses require timedependent parameters which among them time of concentration $\left(T_{c}\right)$ is frequently used parameter (McCuen et al., 1984; Wong, 2009). It is defined as the time required for runoff to travel from the most remote point to the outlet of a catchment (McCuen et al., 1984; Haan et al., 1994) https://en.wikipedia.org/wiki/Time_of_concentration. This parameter reflects the speed at which the watershed responds to rainfall events (Povlovic and Moglen, 2008) and therefore play an important role in estimating peak floods and hydrologic designs. According to the significance of time of concentration, researchers and hydrologist have developed a huge number of empirical, semi-empirical and analytical formulas. So far, several $T_{c}$ equations have been developed that each of them resulted from studies performed in specific regions and hence, researchers are often confused by the many equations and often select a method without evaluating and comparing its accuracy and uncertainty with other formulas (McCuen et al., 1984; Wong and Asce 2005). Most of the developed $T_{c}$ equations usually are based on two different approaches. In the first approach, $T_{c}$ is the time needed for water to travel from the hydraulically or physically most distant point from the catchment's outlet (Kirpich, 1940; Singh, 1988; Fang et al., 2008). Equations are based on this approach depend on geomorphological characteristics, such as flow path length, flow path slope, catchment area, rainfall attributes and land cover-related- coefficients (e.g., 
manning's roughness coefficient, curve number, and retardance factors). In the second approach, $T_{\mathrm{c}}$ is the time distance between the end of effective rainfall and the inflection point of the hydrograph's falling limb (McCuen et al., 1984; Fang et al., 2007; de Almeida et al., 2016). Formulas fall into the first approach, due to depending on several parameters and factors such as map scale, DEM resolution, streams delineation threshold and land coverrelated-coefficients, lead to a great level of uncertainty. How to assess the uncertainties in hydrological model parameters and their impacts on the uncertainty of model simulations has always been a topic of great interest (Zhang et al., 2014). The quantitative evaluation of parameter uncertainty and its influence on the uncertainty of hydrological model simulations is critical in reducing the uncertainty of these simulations and in assessing their effectiveness (Christiaens and Feyen, 2000; Bastola et al., 2008; Hughes et al., 2010). So far, limited studies have been carried out to determine the uncertainty and sensitivity of $T_{c}$ formulas. For example, USWRC (1981) reported that the coefficient of variation of $T_{c}$ varied from 2 to $155 \%$. Kosari et al. (2010) by focusing on four $T_{c}$ formulas (Kirpich, BransbyWilliams, California, and SCS) assessed the sensitivity of them to input parameters and concluded that in low slopes the effect of slope parameter is more considerable than other parameters, but by increasing of slope the importance of other parameters such as river length and SCS curve number will be increased. Wong and Asce (2005) by assessing seven $T_{c}$ formulas on two surfaces: concrete and grass, stated that Chen and Wong formula has the best accuracy for both surfaces. Grison et al. (2008) analyzed 19 observed hydrograph in Pequeno catchment, Brazil and found that due to the uncertainties in determining the end of rainfall event and the inflection point of hydrograph's falling limb, there is about $30 \%$ uncertainty in estimating $T_{c}$ value. McCuen (2009) by using Monte Carlo method found that the uncertainty of the velocity method for small and large watersheds is about 39 and $59 \%$, respectively. Besides, he showed that the accuracy of computed $T_{c}$ is largely controlled by the accuracy of roughness coefficient. Azizian and Shokoohi (2014; 2015a) investigated the scale effects and streams delineation threshold on geomorphological parameters on the performance of KW-GIUH model and found that the coefficients of variation of river length, river mean slope and time of concentration is about $18.8,19.3$ and $21 \%$. There are several statistical and mathematical methods that can be used to propagate input uncertainties through the model into output uncertainties, of which the FirstOrder-Analysis (FOA) proposed by Tung and Mays (1981) is one of the most common methods. The procedure is based on first-order-analysis terms in the Taylor series expansion of the dependent variable about its mean value with respect to one or more independent variables. The major assumption in this procedure is that all independent and dependent variables are the Second Moment Variables (SMV), which means that the behavior of any SMV is completely described by its mean and standard deviation (Bobba et al., 1996). According to the simplicity of this method, it has been applied to many environmental simulators, e.g. hydrological models, flood levee design, dam overtopping assessment and groundwater pollution models (Cheng et al., 2013). As mentioned, a few studies have carried out to determine the uncertainty and sensitivity of $T_{c}$ equations and most of them have focused only on some formulas. Thus, the aim of this study is to determine the uncertainty of about $47 T_{c}$ equations and identify the contribution of all input parameters, such as rainfall intensity, land cover-related-coefficients, the scale of topographic and land cover maps, DEM resolution and streams delineation threshold, on the output uncertainty.

\section{Materials and Methods}

\section{Structure of $T_{c}$ Equations}

The accuracy of hydrological designs is sensitive to the accuracy of the estimated $T_{c}$ (Salimi et al., 2016). In this Research 47 empirical/semi-empirical and analytical equations, presented in Table 1, are used to investigate the uncertainty analysis. As it can be seen, these equations depend on several inputs, but the geomorphological parameters, rainfall attributes, and land cover coefficients play an important role. The average adopted values of land cover-related-coefficients and parameters in the selected equations are summarized in Table 2.

\section{Extraction of Geomorphological Parameters Using QGIS}

Estimation of $T_{c}$ requires some watershed's parameters that should be obtained from topographic maps or Digital Elevation Models (DEMs). By development of Geographical Information System (GIS) over the last years, especially in hydrological modeling, several algorithms have been developed for automatic extraction of geomorphological characteristics. In order to extract the watershed's characteristics in this study, DEMs with different scales (SRTM 90m, ASTER 30m and topographic map with a scale of $1: 25000)$ and different resolutions (varies between 30 and $300 \mathrm{~m}$ ) are used in QGIS environ as an open source software. To extract streams network it is necessary to determine precisely a threshold, which is the percent of watershed total cells poured into the target cell. In some GIS extensions such as ArcHydro and HEC-GeoHMS, the default value for streams delineation threshold is equal $1 \%$ of catchment area or $1 \%$ of maximum flow accumulation grid (Azizian and Shokoohi, 2014; 2015a). Therefore, focusing on this value, the thresholds of $0.25,0.5,1,2$ and $3 \%$ are employed for the extraction of streams network. Meanwhile, d8 algorithm used as the best efficient method for flow tracing (Tarboton, 1991). 
Table 1: Summary of the selected time of concentration equations

\begin{tabular}{|c|c|c|}
\hline Name & Formula & Remark \\
\hline Arizona DOT (ADOT 1993) & $T_{c}=0.0097956 A^{0.1}(1000 \mathrm{~L})^{0.25} L_{c a}^{0.25} S^{-0.2}$ & Data of agricultural basins \\
\hline ASCE (Morgali and Linsley, 1965) & $T_{c}=7.2983 L^{0.6} n^{0.6} i^{-0.4} S^{-0.2}$ & Analysis of the kinematic wave $(\mathrm{L}<0,09 \mathrm{~km})$ \\
\hline \multirow[t]{3}{*}{ Akan and Houghtalen (2003) } & $T_{c}=7.354 L^{0.6} n^{0.6} S^{-0.3}\left(i-K_{s}\right)^{-0.4}+$ & Obtained from simultaneously solve the kinematic \\
\hline & $3.1 K_{s}^{1.33} H_{f} P_{f}\left(1-S_{i}\right) * i^{-2.33}$ & \\
\hline & & wave equation and green-ampt infiltration method \\
\hline Basso (Eslamian and Mehrabi, 2005) & $T_{c}=0.957 \mathrm{~L}^{1.155} H_{m}^{-0.385}$ & N/A \\
\hline Bransby Williams (ASDOT, 1995) & $T_{c}=0.605 L(100 S)^{-0.2} A^{-0.1}$ & Specially recommended to rural basins \\
\hline California Culverts Practice (CDH, 1960) & $T_{c}=0.95 L^{1.155} H^{-0.385}$ & Data of small mountain basins in the USA \\
\hline Carter (1961) & $T_{c}=0.0977 L^{0.6} S^{-0.2}$ & Data of an urban basin in the USA $\left(A<20.72 \mathrm{~km}^{2}\right)$ and \\
\hline Chow (1988) & $T_{c}=0.1602 L^{0.64} S^{-0.32}$ & $\begin{array}{l}(\mathrm{S}<0.005) \\
\text { Data of } 20 \text { rural basins in the USA }\left(0.01-18.5 \mathrm{~km}^{2}\right) \text { and } \\
(0.0051<\mathrm{S}<0.09)\end{array}$ \\
\hline Corps of Engineers (Linsley et al, 1977) & $T_{c}=0.191 L^{0.76} S^{-0.19}$ & Data of 25 rural basins in the USA $\left(A \leq 12 \mathrm{~km}^{2}\right)$ \\
\hline Desbordes (Silveira, 2005) & $T_{c}=0.0869 A^{0.3039} S^{-0.3832} A_{i m p}^{-0.4523}$ & $\mathrm{~N} / \mathrm{A}$ \\
\hline DNOS (Silveira, 2005) & $T_{c}=0.419 k^{-1} A^{0.2} L^{0.2} S^{-0.4}$ & Data of 6 rural basins in the USA $\left(A<0.45 \mathrm{~km}^{2}\right)$ and \\
\hline Dooge (1973) & $T_{c}=0.365 A^{0.41} S^{-0.17}$ & $\begin{array}{l}(0.03<\mathrm{S}<0.1) \\
\text { Data of } 10 \text { rural basins in Ireland }\left(145-948 \mathrm{~km}^{2}\right)\end{array}$ \\
\hline Epsey (Hotchkiss and McCallum, 1995) & $T_{c}=6.89 L^{0.36} S^{-0.18}$ & Data of 11 rural basins in the USA \\
\hline Epsey and Winslow (McCuen, 1998) & $T_{c}=0.45 \Phi L^{0.29} S^{-0.11} i^{-0.6}$ & Obtained from 17 rural and urbanized basins range \\
\hline Egelson (1962) & $T_{c}=0.275 n L R^{-0.667} S^{-0.5}$ & $\begin{array}{l}\text { from } 1 \text { to } 35 \mathrm{mi}^{2} \\
\text { Calibrated from data for catchments less than } 8 \mathrm{mi}^{2}\end{array}$ \\
\hline FAA (1970) & $T_{c}=0.3788(1.1-C) L^{0.5} S^{-0.332}$ & Data of airports' drainage \\
\hline Flavell (1983) & $T_{c}=2.31 A^{0.54}$ & Obtained from observed times of hydrograph rise on \\
\hline Morgali and Linsley (1965) & $T_{c}=7.354 n^{0.6} L^{0.6} S^{-0.3} i^{-0.4}$ & $\begin{array}{l}\text { basins in the south west of Western Australia } \\
\text { For small urban areas with drainage areas less than } 10\end{array}$ \\
\hline Ragan and Duru (1972) & $T_{c}=7.275 n^{0.6} L^{0.6} S^{-0.3} i^{-0.4}$ & $\begin{array}{l}\text { or } 12 \text { acres and useful for drainage is basically planar } \\
\text { Based on the kinematic wave equation }\end{array}$ \\
\hline Ribeiro (1961) & $T_{c}=0.267(1.05-0.2 p)^{-1} L S^{-0.04}$ & Data of 7 rural basins in the USA and a rural basin in \\
\hline & & India $\left(\mathrm{A}<19000 \mathrm{~km}^{2}\right)$ and $(0.03<\mathrm{S}<0.1)$ \\
\hline Giandotti (1934) & $T_{c}=(4 \sqrt{A}+1.5 L) /\left(0.8 \sqrt{H_{m}}\right)$ & Data of basins in central and northern Italy $\left(170-70000 \mathrm{~km}^{2}\right)$ \\
\hline Haktanir and Sezen (1990) & $T_{c}=0.7473 L^{0.841}$ & Data of 10 basins in Turkey $\left(11-9867 \mathrm{~km}^{2}\right)$ \\
\hline Izzard (1946) & $T_{c}=85.5\left(i / 36286+C_{r}\right) i^{-0.667} L^{0.33} S^{-0.333}$ & $\begin{array}{l}\text { Based on a series of laboratory experiments by the Bureau of } \\
\text { public roads. This method is designed for applications in } \\
\text { which the product of intensity and flow length is than } 500\end{array}$ \\
\hline Johnstone and Cross (1949) & $T_{c}=0.4623 L^{0.5} S^{-0.25}$ & Data of 19 rural basins in the USA $\left(64.8-4206.1 \mathrm{~km}^{2}\right)$ \\
\hline Kerby (1959) Hathaway (1945) & $T_{c}=0.6061 N^{0.47} L^{0.47} S^{-0.234}$ & $\begin{array}{l}\text { Analysis of overland flow in experimental surfaces } \\
(\mathrm{L}<0.37 \mathrm{~km})\end{array}$ \\
\hline Kinematic wave & $T_{c}=7.35 n^{0.6} i^{-0.4} L^{0.6} S^{-0.2}$ & Analysis of overland flow in experimental surfaces \\
\hline (Kibler and Aron, 1983) & & $(\mathrm{L}<0.03 \mathrm{~km})$ \\
\hline Kirpich-Tennessee (Kirpich, 1940) & $T_{c}=0.0653 L^{0.77} S^{-0.385}$ & $\begin{array}{l}\text { Data of small watersheds in Tennessee and Pennsylvania } \\
\left(0.004-0.453 \mathrm{~km}^{2}\right) \text { and }(0.03<\mathrm{S}<0.1)\end{array}$ \\
\hline Kirpich-Pennsylvania (Kirpich, 1940) & $T_{c}=0.01104 L^{0.77} S^{-0.5}$ & \\
\hline McCuen et al. (1984) & $T_{c}=2.2535 i^{-0.7164} L^{0.5552} S^{-0.207}$ & Starting from data of 48 urban basins in the USA ( $0.4-6$ \\
\hline Papadakis and Kazan (1986) & $T_{c}=\left(2.1539 n^{0.52} L^{0.5}\right) /\left(i^{0.38} S^{0.31}\right)$ & $\begin{array}{l}\left.\mathrm{km}^{2}\right) \text { and }(0.0007<\mathrm{S}<0.03) \\
\text { Data of } 84 \text { small rural basins in the USA }\left(\mathrm{A}<5 \mathrm{~km}^{2}\right)\end{array}$ \\
\hline Pasini (1914) & $T_{c}=0.108 A^{0.332} L^{0.332} S^{-0.5}$ & Data of rural basins in Italy \\
\hline Pickering (Mata-Lima et al. 2007) & $T_{c}=0.9482 L^{1.155} H^{-0.385}$ & Equivalent to Kirpich's \\
\hline Picking (Silveira 2005) & $T_{c}=0.0883 L^{0.667} S^{-0.332}$ & Data of rural basins \\
\hline Pilgrim and Mac Dermott (1982) & $T_{c}=0.76 A^{0.38}$ & Developed from 96 basins in eastern New South Wales \\
\hline Overton and Meadows (1976) & $T_{c}=22.92 n^{0.8} L^{0.8} S^{-0.4} P_{2}^{-0.5}$ & $\mathrm{~N} / \mathrm{A}$ \\
\hline SCS Lag (Mockus, 1961) & $T_{c}=0.057((1000 / C N)-9)^{0.7} L^{0.8} S^{-0.5}$ & Data of 24 rural basins in the USA $\left(A<8 \mathrm{~km}^{2}\right)$ \\
\hline SCS Ave Velocity (NRCS, 1972; 1986) & $T_{c}=0.278 \sum L / K S^{0.5}$ & This method relates watershed slope and surface to flow velocity \\
\hline
\end{tabular}




\begin{tabular}{|c|c|c|}
\hline Simas and Hawkins (2002) & $T_{c}=0.322 \mathrm{~A}^{0.594} L^{-0.594} S^{-0.15} S_{s c s}^{0.312}$ & Data of 168 basins in the USA $\left(0.001-14 \mathrm{~km}^{2}\right)$ \\
\hline Schaake et al. (1967) & $T_{c}=0.0828 L^{0.24} S^{-0.16} \mathrm{~A}_{\text {imp }}^{-0.26}$ & N/A \\
\hline Sheridan (1994) & $T_{c}=2.20 L^{0.92}$ & nine flatland watersheds located in Georgia and Florida \\
\hline & & and ranging in size from 2.62 to $334.34 \mathrm{~km}^{2}$ \\
\hline Temez (1987) & $T_{c}=0.3 L^{0.76} S^{-0.19}$ & Data of natural basins in Spain \\
\hline Van Sickle (1962) & $T_{c}=0.0081 L_{t}^{0.13} L_{m}^{0.13} S^{-0.065}$ & Calibrated from data collected in Houston, with drainage \\
\hline & & areas less than $36 \mathrm{mi}^{2}$ \\
\hline Ventura (Mata-Lima et al., 2007) & $T_{c}=4 A^{0.5} L^{0.5} H^{-0.5}$ & Data of rural basins in Italy \\
\hline Williams (1922) & $T_{c}=0.272 A^{0.4} L D^{-1} S^{-0.2}$ & Data of basins in India $\left(A<129,5 \mathrm{~km}^{2}\right)$ \\
\hline Woolhiser and Liggett's & $T_{c}=7.3015 n^{0.6} L^{0.6} i^{-0.4} S^{-0.5}$ & Based on the theory of kinematic wave \\
\hline (1967, Wong and Asce, 2005) & & \\
\hline Yen and Chow's (1983) & $T_{c}=1.2 n^{0.6} L^{0.6} S^{-0.5}$ & Based on the theory of the kinematic wave \\
\hline Zomorodi (2005) & $T_{c}=0.1101 n^{0.75} L^{0.75} S^{-0.375}$ & Modified version of NRCS method \\
\hline
\end{tabular}

Note: $\mathrm{T}_{\mathrm{c}}$ : time of concentration (hr), A: catchment area $\left(\mathrm{Km}^{2}\right), \mathrm{C}$ : runoff coefficient, CN: SCS Curve-number, D: equivalent diameter of the catchment $(\mathrm{Km}), \mathrm{H}$ : quota difference between the ends of the main channel $(\mathrm{m}), \mathrm{H}_{\mathrm{m}}$ : mean altitude in the catchment $(\mathrm{m})$, i: rainfall intensity $(\mathrm{mm} / \mathrm{h}), \mathrm{K}$ : coefficient of the type of surface, L: flow path length $(\mathrm{Km})$, $\mathrm{L}_{\mathrm{ca}}$ : mean length starting from the concentration spot along the $\mathrm{L}$ up to the spot where $\mathrm{L}$ is perpendicular to the centroid of the catchment (m), N: retardance coefficient, $\mathrm{n}$ : Manning's roughness coefficient, p: relation between the vegetation cover and the total area of the basin, S: flow path slope $(\mathrm{m} / \mathrm{m}), \mathrm{S}_{\mathrm{scs}}$ : maximum capacity of retention $(\mathrm{mm}), \mathrm{C}_{\mathrm{r}}$ : retardance coefficient (ranges from 0.007 to 0.06$)$, I: percent of impervious area, $\mathrm{P}_{2}$ : maximum $24 \mathrm{~h}$ rainfall with return period of $2(\mathrm{~mm}), \mathrm{P}_{\mathrm{f}}$ : soil suction head $(\mathrm{mm}), \mathrm{S}_{\mathrm{i}}$ : saturated moisture content, $\mathrm{H}_{\mathrm{f}}$ : soil porosity and $\mathrm{K}_{\mathrm{s}}$ : saturated hydraulic conductivity $(\mathrm{mm} / \mathrm{hr}), \mathrm{N} / \mathrm{A}$ : Not available data

Table 2: Adopted values of the coefficients and parameters in the selected equations

\begin{tabular}{llr}
\hline Formula & Coefficient & Adopted value \\
\hline Akan & $\mathrm{P}_{\mathrm{f}}$ & 150.200 \\
Akan & $\mathrm{H}_{\mathrm{f}}$ & 0.300 \\
Akan & $\mathrm{K}_{\mathrm{s}}$ & 3.400 \\
Akan & $\mathrm{Si}$ & 0.250 \\
DNOS & $\mathrm{k}$ & 4.450 \\
Epsey-Winslow & $\Phi$ & 0.150 \\
FAA & $\mathrm{C}$ & 0.190 \\
Izzard & $\mathrm{C}_{\mathrm{r}}$ & 0.014 \\
Kerby-Hathaway & $\mathrm{N}$ & 0.330 \\
Kinematic Wave/Eagleson/ASCE/Papadakis-Kazan/Overton-Meadows/Yen & $\mathrm{n}$ & 0.023 \\
-Chow's/Zomorodi/Woolhiser-Liggett's/Ragan-Duru/Morgali-Linsley/Akan & & 14.500 \\
Overton-Meadows & $\mathrm{P}_{2}$ & 0.240 \\
Ribeiro & $\mathrm{p}$ & 0.110 \\
Schaake/Desbordes/Epsey & $\mathrm{A}_{\text {imp }}$ & 78.200 \\
SCS Lag/Simas-Hawkins & $\mathrm{CN}$ & \\
\hline
\end{tabular}

\section{Uncertainty Analysis Method}

An uncertainty analysis is not the same as a sensitivity analysis. An uncertainty analysis attempts to describe the entire set of possible outcomes, together with their associated probabilities of occurrence (Loucks et al., 2005). In the design and analysis of hydro systems, many quantities of interest are functionally related to a number of variables, some of which are subject to uncertainty. A rather useful technique for the approximation of uncertainties is the First-Order-Analysis (FOA) of uncertainties, sometimes called the delta method. This method is very popular in many fields of engineering because of its relative ease in application to a wide range of problems (Mays and Tung, 2002). FOA method is used to estimate the uncertainty in a deterministic model formulation involving parameters that are uncertain. More specifically, FOA method enables one to estimate the mean and variance of a random variable that is functionally related to several other variables, some of them are random. By using first-order analysis, the combined effect of uncertainty in a model formulation, as well as the use of uncertain parameters, can be assessed. Consider a random variable $y$ that is a function of $k$ random variables (Mays and Tung, 2002):

$y=g\left(x_{1}, x_{2}, \ldots, x_{k}\right)$

This function can be a deterministic equation such as rational formula, time of concentration equations, Manning's equation or it can be a complex model that must be solved on a computer (Mays and Tung, 2002). The objective is to treat a deterministic model that has uncertain inputs in order to determine the effect of the 
uncertain parameters $x_{1}, x_{2, \ldots,} x_{k}$ on the model output $y$. equation (1) can be expressed as $y=g(x)$ where $x=x_{1}$, $x_{2}, \ldots x_{k}$. Through a Taylor series expansion about $k$ random variables, ignoring the second and higher order terms, the approximate form could be obtained via Equation 2:

$$
y \approx g(\overline{\mathrm{x}})+\sum_{i=1}^{k}\left[\frac{\partial g}{\partial x_{i}}\right]_{\overline{\mathrm{x}}}\left(X_{i}-\bar{x}_{i}\right)
$$

The derivatives $\left[\partial g / \partial x_{i}\right]$ are the sensitivity coefficients that represent the rate of change of the function value $g(x)$ at $x=\bar{x}$. Assuming that the $\mathrm{k}$ random variables are independent and then the variance of $y$ is approximated as:

$$
\sigma_{y}^{2}=\operatorname{Var}[y]=\sum a_{i}^{2} \sigma_{x_{i}}^{2}
$$

And the coefficient of variation is $\Omega_{y}$ :

$$
\Omega_{y}=\left[\sum_{\tau=1}^{k} a_{i}^{2}\left(\frac{\bar{x}_{i}}{\mu_{y}}\right)^{2} \Omega_{x_{i}}^{2}\right]^{0.5}
$$

where, $a_{i}=(\partial g / \partial x)_{\bar{x}}$.

By considering the general form of $T_{c}$ equations, shown in Equation 7, the total uncertainty of each $T_{c}$ equation could be obtained via Equation 6:

$$
\begin{aligned}
& T_{c}=a \cdot S^{b} L^{c} A^{d} n^{e} i^{f} H^{g} H_{m}^{h} \\
& \Omega_{T_{c}}^{2}=b^{2} \Omega_{S}^{2}+c^{2} \Omega_{L}^{2}+d^{2} \Omega_{A}^{2}+e^{2} \Omega_{n}^{2}+f^{2} \Omega_{i}^{2}+g^{2} \Omega_{H}^{2}+h^{2} \Omega_{H_{m}}^{2}
\end{aligned}
$$

where, a, b, c, d, e, f, g, h are the exponents of each input parameters. The dependency of $T_{c}$ equations to different parameters which generally includes rainfall intensity, scale of topographic and land cover maps, DEM resolution, DEM creation method (scale effects) and streams delineation threshold impose significant uncertainties to the input parameters and the output of $T_{c}$ equations. Several studies have been carried out to show the scale effects on the catchment's geomorphological parameters (Wolock and Price, 1994; Pradahan et al., 2008; Hancock, 2005; Azizian and Shokoohi, 2015a; 2015b) and therefore this issue is one of the main uncertainty sources. Moreover, land cover maps with different scales lead to different values for land coverrelated-coefficients which are used in the most $T_{c}$ equations. Besides, rainfall attributes variations, due to playing an important role, should be considered as another uncertainty sources. In the present study, uncertainty analysis has been carried considering the following cases:

- Case I: Considering the uncertainty associated with all geomorphological characteristics (e.g., flow path length, flow path slope, area), rainfall attributes (e.g., the 2-year, 2-h rainfall intensity) and land cover-related-factors (e.g., retardance and Manning's roughness coefficient)

- $\quad$ Case II: Considering the uncertainty associated with geomorphological characteristics and their contribution on the output uncertainty.

- Case III: Considering the uncertainty associated with rainfall attributes (e.g., the 2-year, 2-h rainfall intensity) and land cover-related-factors and their contribution on the output uncertainty.

\section{Study Area}

In this research, Kasilian and Amameh watersheds with different climate and topographic conditions are used. Both of them are located in the north of Iran in regions with humid and dry climate, respectively. Kasilian watershed, in the central Alborz mountain chain, is a mountainous area covered by forest. This watershed with an area of $67 \mathrm{Km}^{2}$ and a perimeter of $37.8 \mathrm{Km}$ is drained by the Kasilian River with a length of $17 \mathrm{Km}$. Amameh watershed, in the south Alborz mountain chain, is one the sub-basins of Jajrood watershed with an area of $37.2 \mathrm{Km}^{2}$ and a perimeter of $29.1 \mathrm{~km}$. The average slope of Kasilian and Amameh watersheds is about 16.4 and $13.0 \%$, respectively. In order to extract watersheds' characteristics in this study, SRTM 90m, ASTER 30m DEMs and topographic maps with a scale of 1:25000 are used to create DEMs with different cell sizes $(30$ to $300 \mathrm{~m})$. Furthermore, for estimation of land cover-related-coefficients such as n, C, K, N, and Cr map with scales of 1:50000, 1:100000, 1:250000 and different recommended tables (e.g., Chow, 1964; McCuen, 2009) are used. The location of Kasilian and Amameh watersheds and their Digital Elevation Models (DEMs) are shown in Fig. 1.

\section{Results and Discussion}

\section{Scale Effects (Map Scale and DEM Resolution) on the Geomorphological Parameters}

Different thresholds (0.25-3\%), various maps (Topo, SRTM, and ASTER DEMs) and several DEM resolutions (25-300 meter) are used for extraction of geomorphological parameters that required for $T_{c}$ equations. Because of the huge number of extracted data, only parameters that obtained in Kasilian catchment (at different scales) at thresholds of 0.25 and $3 \%$ are shown in Fig. 2-8. Findings illustrate that in all stream orders the mean slope of rivers and sub-basins that obtained from Topo DEM are lower than that of from SRTM and ASTER DEMs. For instance, the main channel slope based on Topo and SRTM DEMs at the threshold of $0.25 \%$ is about 5.3 and $6.5 \%$, respectively. In addition, at the threshold of $3 \%$ the mentioned values are 1.9 and $3.3 \%$, respectively. Generally, the mean slope of the main channel varies between 1.9 and $6.5 \%$. 


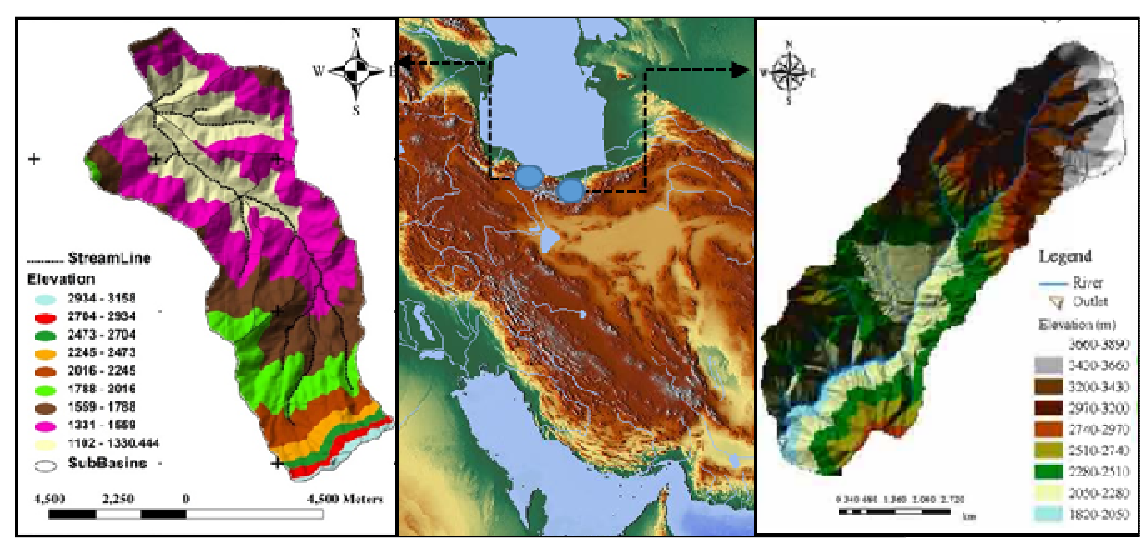

Fig. 1: Location and the DEM of the study areas

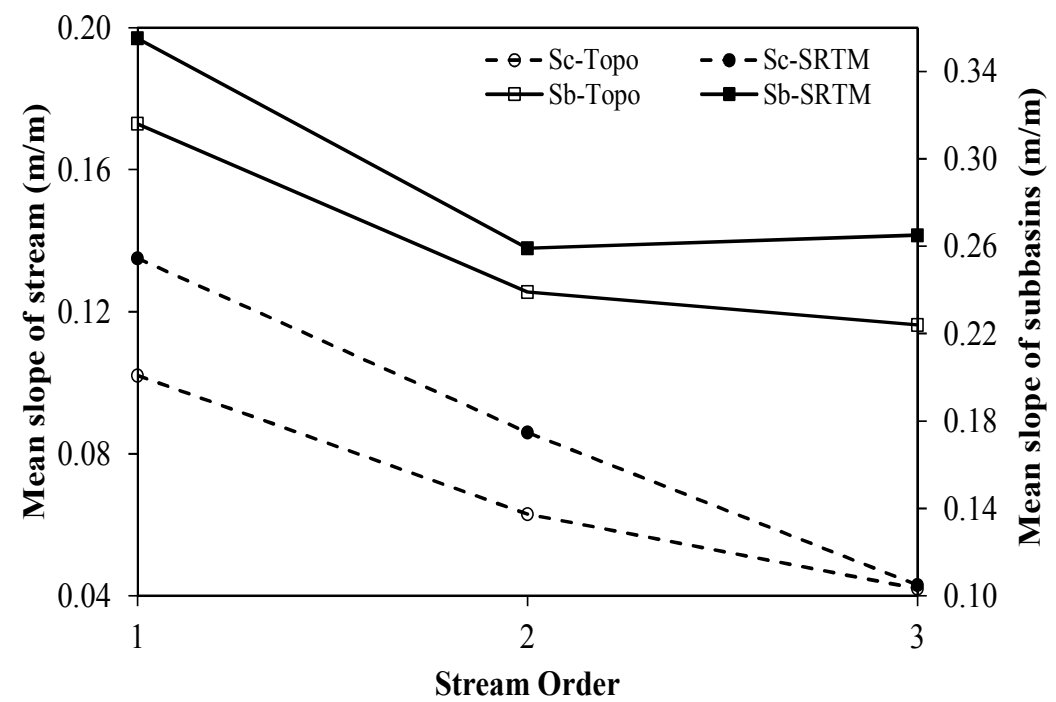

Fig. 2: Effect of data resolution on the mean slope of streams and sub-basins of i-th order streams at threshold 0. 5\% (DEM-50m)

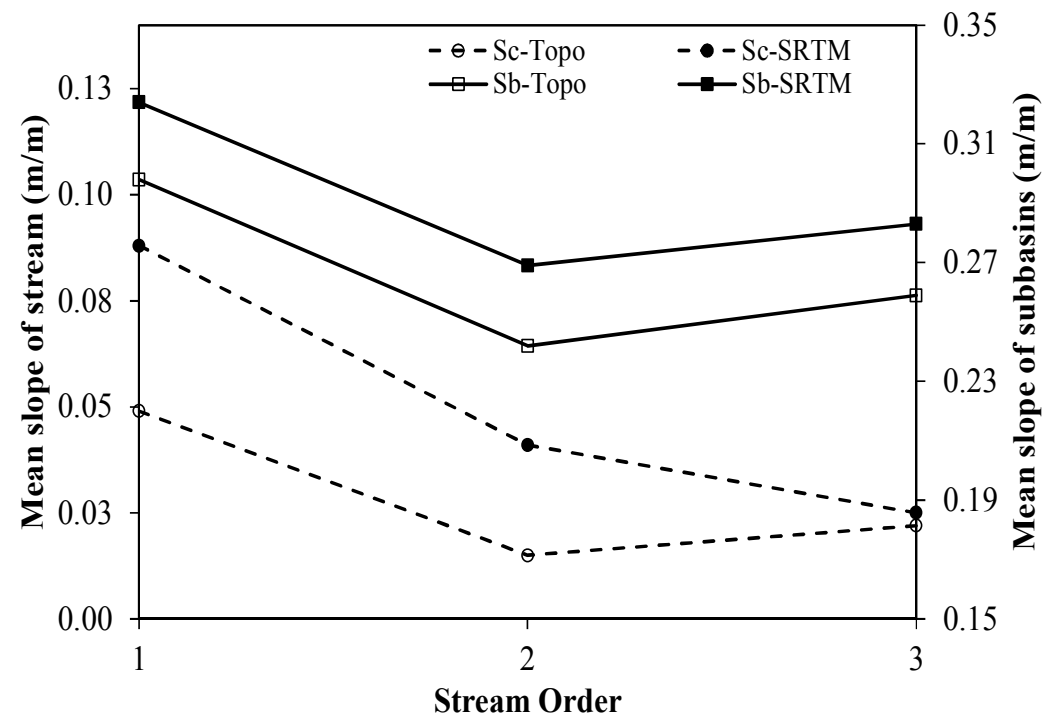

Fig. 3: Effect of Data resolution on the mean slope of streams and sub-basins of i-th order streams at threshold 3\% (DEM-50m) 


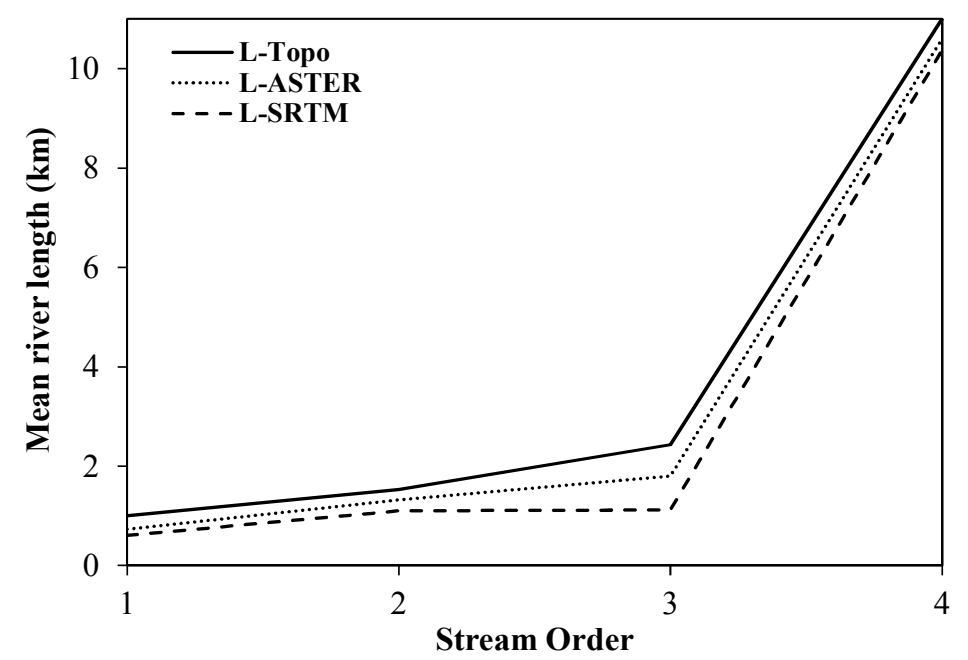

Fig. 4: Effect of data resolution on the mean length of $\mathrm{i}$-th order streams at threshold $0.25 \%$ (DEM-50m)

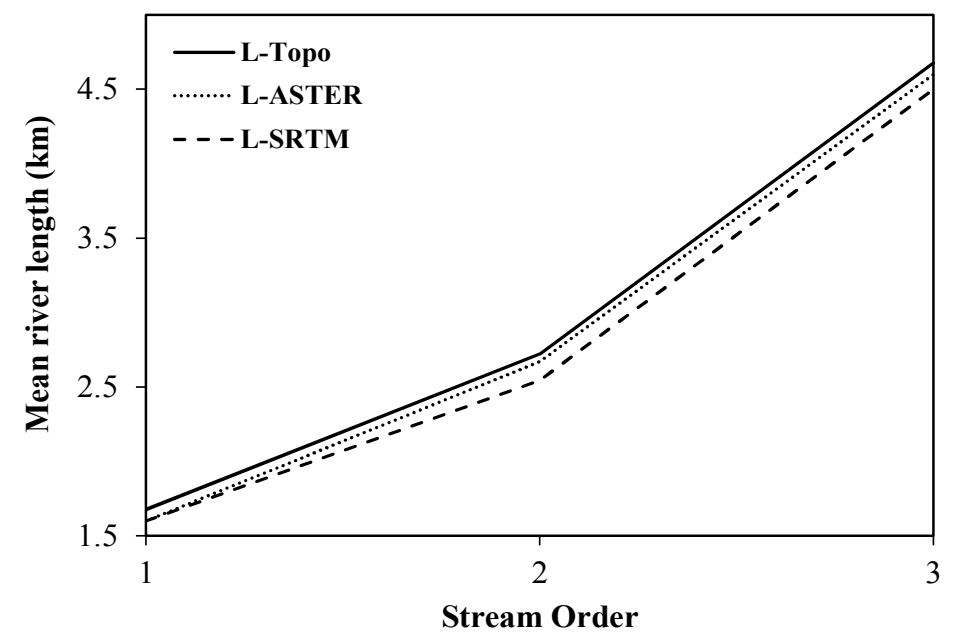

Fig. 5: Effect of data resolution on the mean length of i-th order streams at threshold 3\% (DEM-50m)

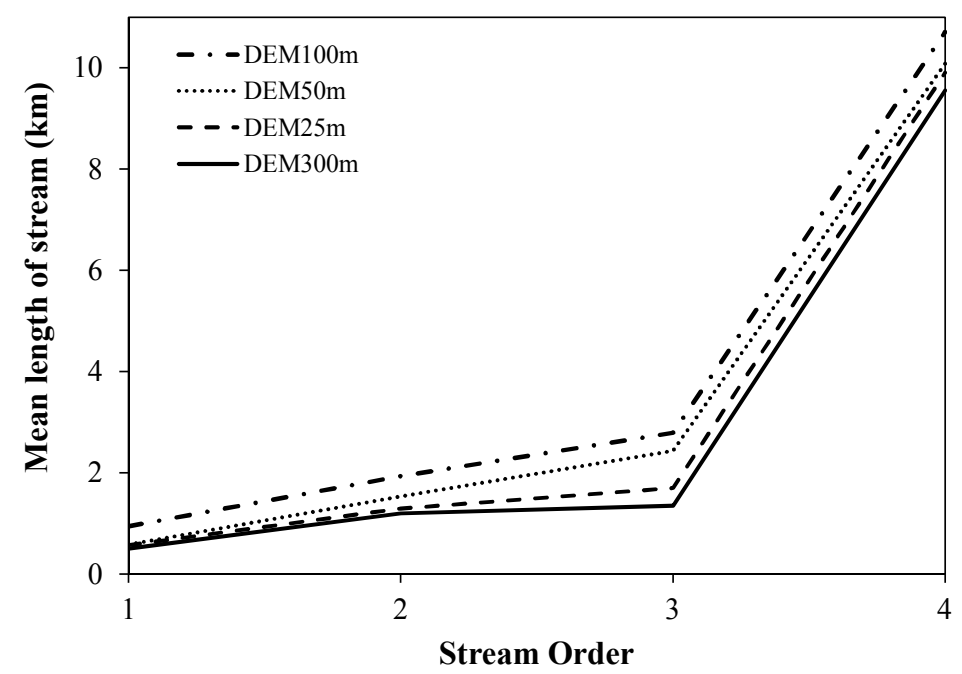

Fig. 6: Effect of DEM resolution on the mean length of i-th order streams at threshold $0.25 \%$ 


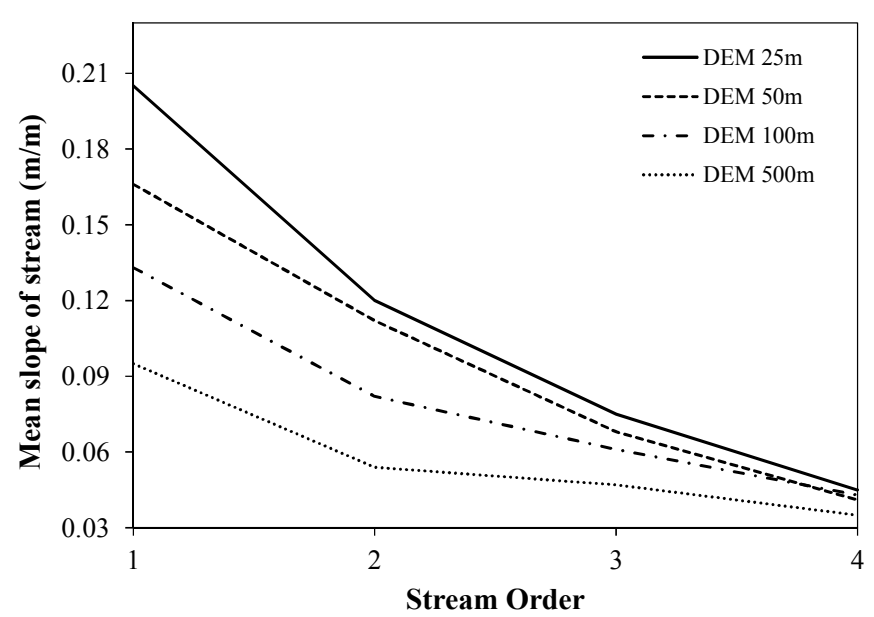

Fig. 7: Effect of DEM resolution on the mean slope of i-th order streams at threshold $0.25 \%$

Moreover, because of scale effects and different thresholds, the main channel length and mean slope of sub-basins vary between $6.43-14.04 \mathrm{~km}$ and $22.1-31.2 \%$, respectively. The slope of both overland and channel parts affects the travel time of raindrop and flood wave velocity moving towards the basin outlet. Therefore, it can be expected that, due to the greater slope and smaller channel length of SRTM DEMs, the time of concentration will be greater than that estimated from Topo and ASTER DEMs. Besides, when DEM resolution gets coarser the information content of all maps with different scales reaches to a constant value and this issue results the same watershed's characteristics. As it can be seen, different map scales and streams delineation threshold have considerable effects on the values of geomorphological parameters and therefore one can conclude that these factors are one the most important sources of uncertainty in estimating of $T_{c}$ values.

\section{Uncertainty Analysis of $T_{c}$ Equations}

For estimation of uncertainty based on FOA method, Coefficient of Variation (CV), variance and mean values of each input parameter should be identified. According to the statistical analysis, the probability distribution of flow path Length (L), flow path Slope (S) and the difference between the elevations of endpoints of river (H) follow as Gama distribution, while rainfall intensity, Manning's roughness coefficient and most of the other land cover-related-coefficients follow as log-normal distribution. These findings show broad agreement with McCuen (2009) studies that assumed all input parameters of velocity method follow a gamma distribution. Needless to say that the variation of the catchment area and perimeter values in different data resolution and DEM resolution aren't significant and therefore they assumed as constant values. After identifying the probability distributions the coefficient of variation and mean values of all input parameters can be easily calculated. To keep the paper in reasonable extend only the results that obtained in Kasilian catchment presented in this section. The uncertainty of all $T c$ formulas and the contribution of each parameter on the total uncertainty are shown in Fig. 8-11.

\section{Case 1}

Results indicate that, based on $\mathrm{CV}$ value, $T c$ equations could be categorized into two different groups. Group1 contains the equations which depend on all parameters, while in group2 $T c$ formulas are only based on watershed's characteristics. In the first group, the minimum, mean and maximum values of uncertainty are about 36.7, 49.9 and $61.4 \%$, respectively. In this group, Overton-Meadows and Yen-Chow equations result the highest and lowest uncertainty, respectively. One of the most important factors that affect the CV value in this group is the dependency to different parameters with a wide range of variations. For example, the $\mathrm{CV}$ value of rainfall intensity and Manning's roughness coefficient in Kasilian catchment is about 82 and $50 \%$, respectively and this issue leads to higher uncertainty. In contrast to group1, the uncertainty of second group's equations is relatively low and the maximum and minimum values of $\mathrm{CV}$ in this group are about 28.4 and $0.5 \%$, respectively. In this group, Pilgrim-McDermott and Flavell formulas because of depending only on catchment Area (A) and according to the low variation of this parameter in different map scales, result low uncertainty. Moreover, the exponent of watershed's characteristics plays an important role on the uncertainty of $T c$ equations. In the next sections, the relationship between some parameters' exponents and their contributions on the total uncertainty will be discussed. 


\section{Case 2}

Findings reveal that the importance of geomorphological parameters, such as flow path Length $(\mathrm{L})$ and flow path slope $\left(\mathrm{S}_{\mathrm{c}}\right.$ or $\left.\mathrm{S}_{\mathrm{b}}\right)$, on the total uncertainty, is different in both groups (Fig. 9 and 10). In the first group, the contribution of geomorphological characteristics is relatively low. For instance, in Epsey-Winslow, ASCE and Eagleson equations the uncertainty associated with flow path length is about 1.0, 7.9 and $13.9 \%$ (Fig. 9), respectively and the uncertainty caused by flow path slope isn't significant (about 0.5, 1.0 and 7.8\%, respectively). In the second group's equations geomorphological parameters, especially flow path length and flow path slope, play an important role on the output uncertainty. As shown in Fig. 9, the percentage of uncertainty that caused by flow path length in the second group varies between 29 and $100 \%$. Also, in about $66 \%$ of all Tc equations (31 formulas) flow path length contributes more than $30 \%$ on the total uncertainty. Compared to flow path length, flow path slope parameter leads to lower contribution and almost in about $50 \%$ of all $T c$ formulas it contributes lower than $20 \%$ (Fig. 10).

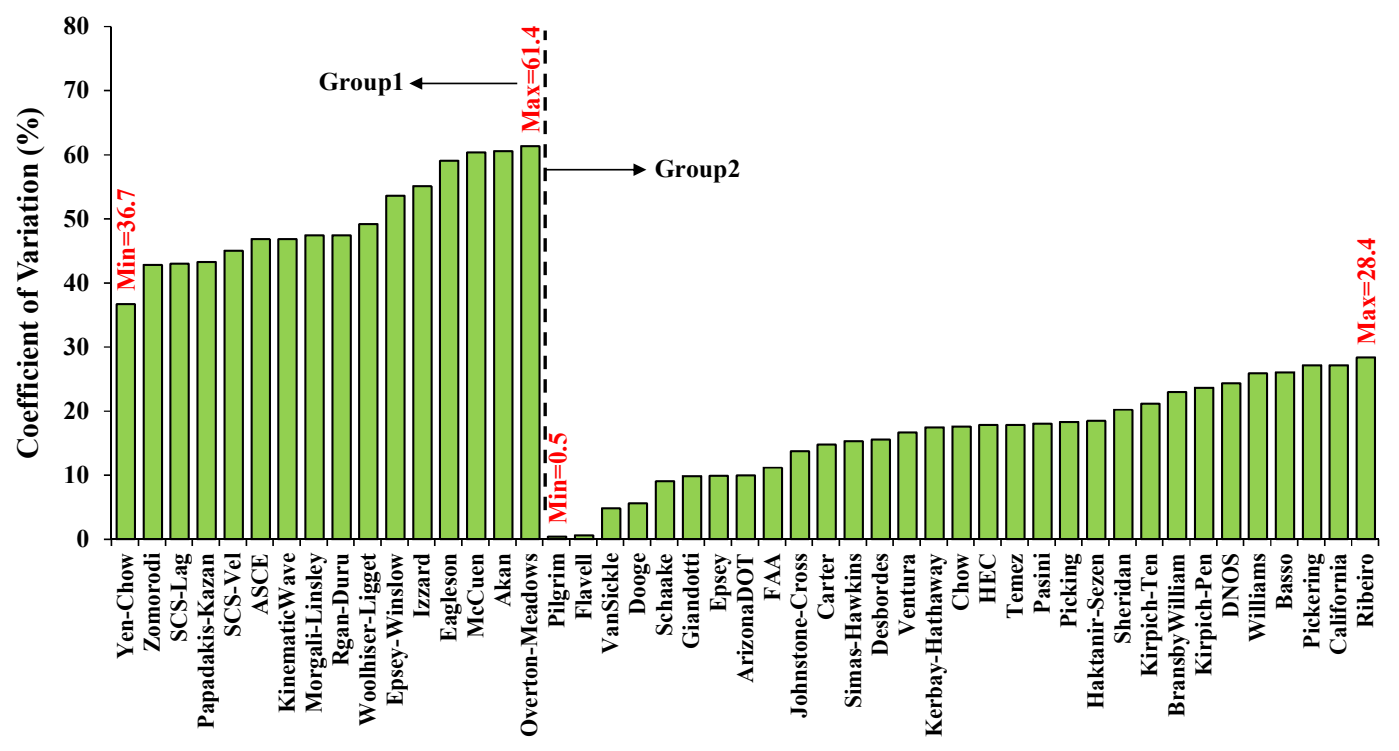

Fig. 8: Coefficient of Variation of all $T_{c}$ Equations

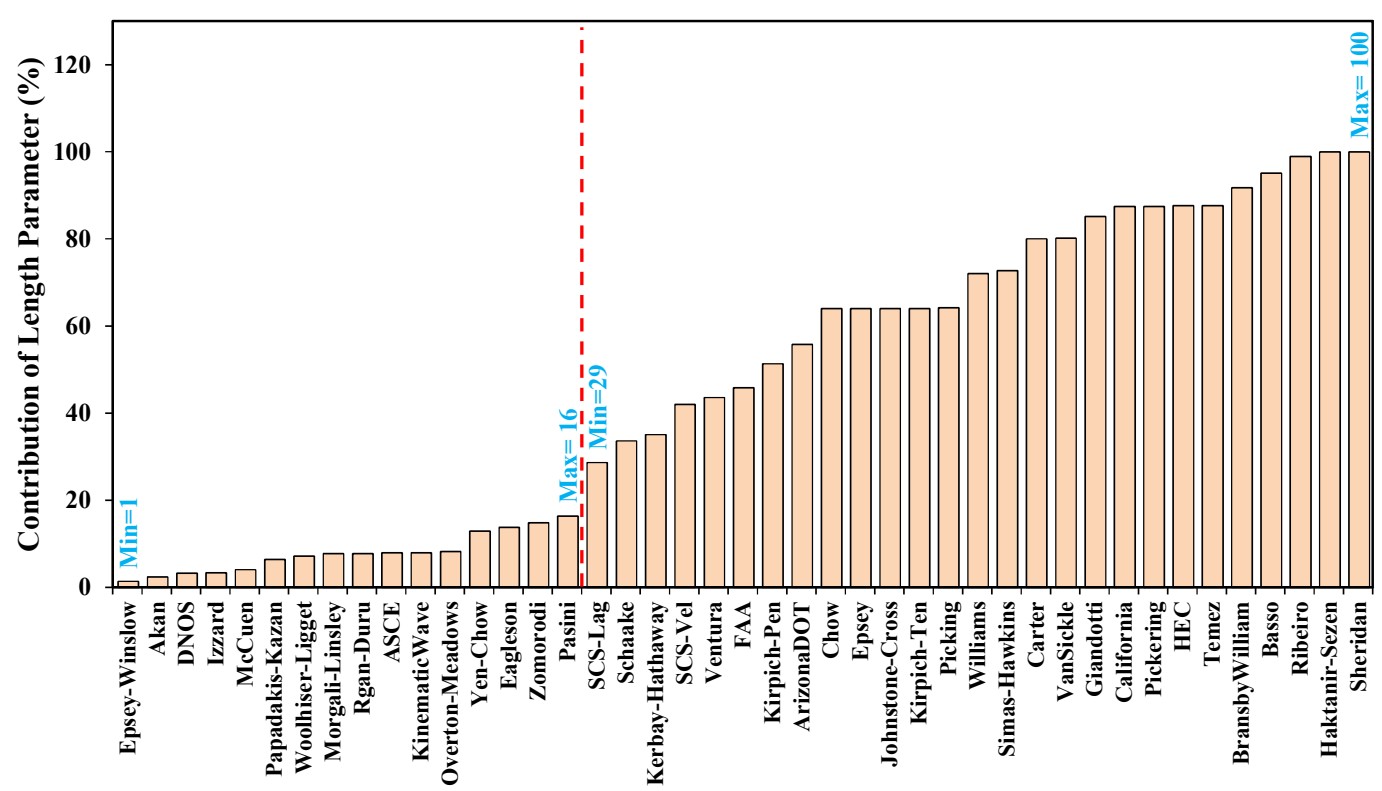

Fig. 9: The Contribution of Flow Path Length on the Total Uncertainty of $T_{c}$ Equations 


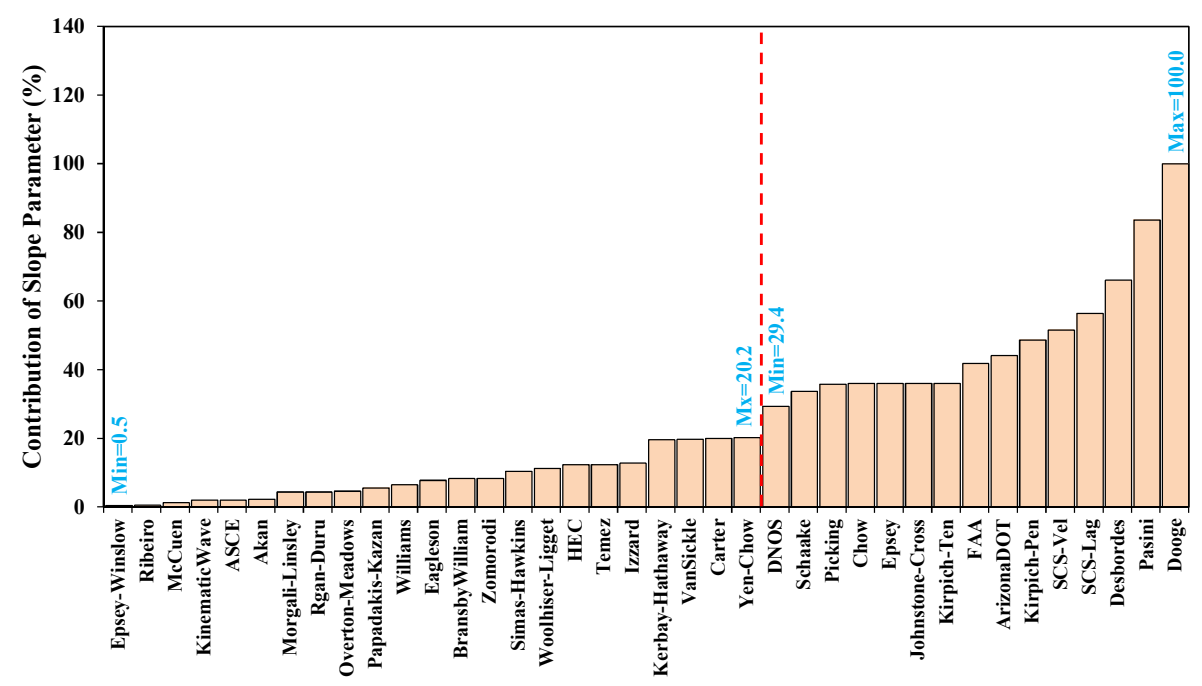

Fig. 10: The Contribution of flow path slope on the total uncertainty of $T_{c}$ equations

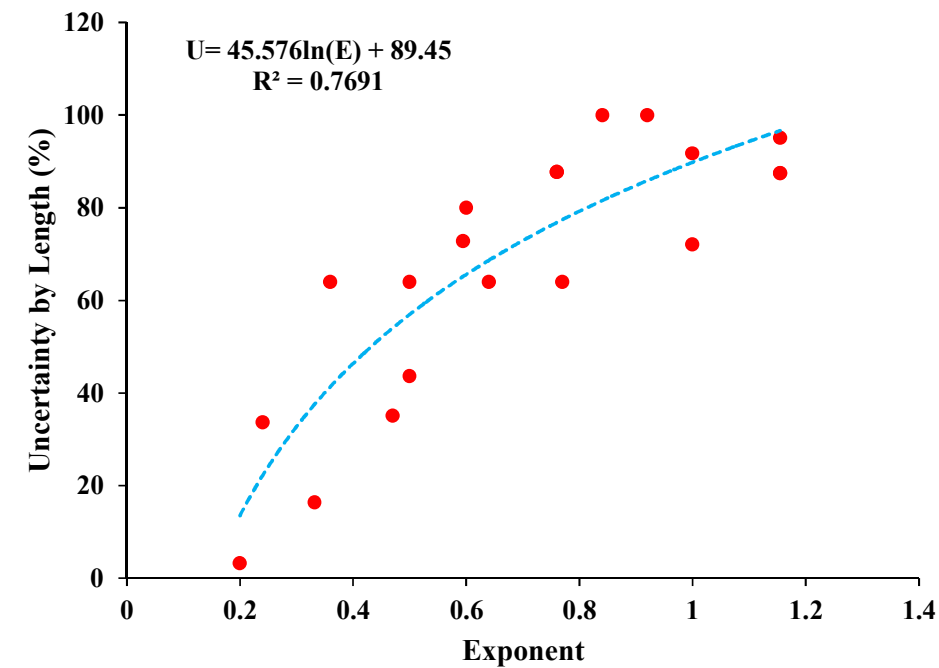

(a)

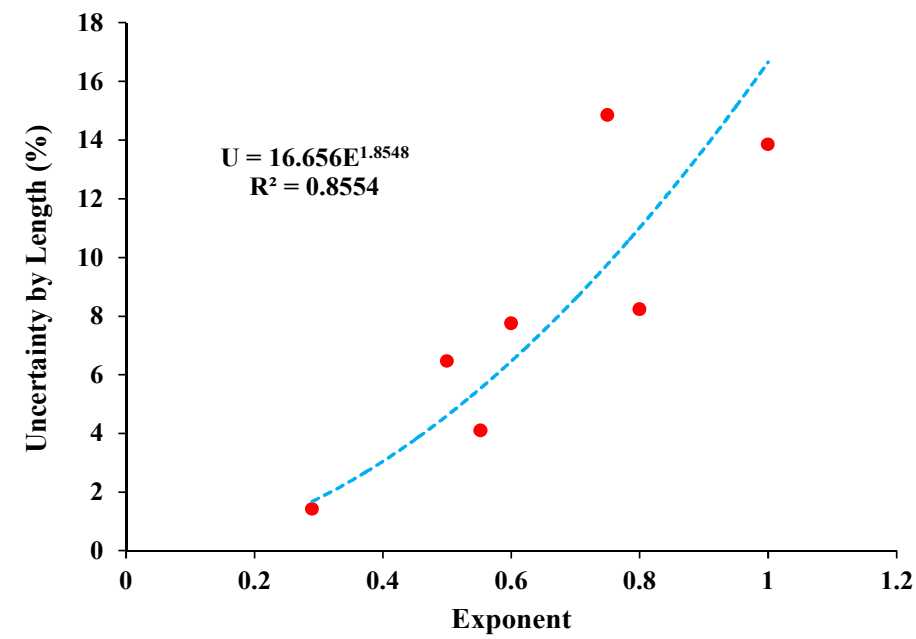

(b)

Fig. 11: Variation of Flow Path Length Exponent and its Contribution on the Output Uncertainty a) Group 1 b) Group 2 
There are a huge number of reasons that affect the contribution of each parameter on the output uncertainty, but the most important one is the value of parameters' exponent especially flow path length's exponent. The findings from the research illustrate that by increasing the exponent of each parameter the uncertainty of $T_{c}$ equations and the contribution of that parameter increases. For example, in group 2 there is a significant relationship between the exponent of flow path length parameter and its contribution on the total uncertainty. As shown in Fig. 11, by increasing the flow path length's exponent from 0.2 to 1.155 , the uncertainty associated with this parameter increases to reach the maximum value $(100 \%)$. In addition, in the group 1 , although the exponent varies between 0.3 and 1 , the maximum value of flow path length's contribution is lower than $15 \%$ and this means that the watershed's features play a minor role in the estimation of $T_{c}$ value with the first group's equations.

\section{Case 3}

As mentioned, land cover-related-coefficients play a key role in estimating $T_{c}$ and other hydrological processes. The values of these coefficients depend on the scale of map and field observations and hence, for a specific region different values could be obtained. Investigation of the effects of these coefficients on the output uncertainty demonstrates that if there is no accurate estimation for them it leads to significant sensitivity and uncertainty in estimating $T_{c}$ value. The effect of land cover coefficients on the uncertainty of $T_{c}$ equations is shown in Fig. 12. It can be concluded from this figure that inaccurate estimation of land cover coefficients leads to higher uncertainty. For instance, the uncertainty in manning's roughness parameter contributes to 76.8 and $71.6 \%$ in estimating $T_{c}$ value by Zomorodi and Eagleson formulas. Besides, in some equations such as Epsey-Winslow and Izzard, because of the higher variation in rainfall intensity especially in humid regions, the effects of land cover coefficients are not considerable and the maximum contribution is lower than $14 \%$.

In comparison to geomorphological-based formulas (group 2), the uncertainty caused by rainfall intensity and Manning's roughness coefficient is more considerable. It should be noted that the contribution of rainfall intensity and Manning's roughness (group 1) on the output uncertainty are completely different in both catchments and affected by climate conditions and land cover variety. Kasilian catchment, due to being located in humid climate, experiences remarkable variations of rainfall intensity and land cover types rather than Amameh catchment. The results, shown in Fig. 13, express that the average uncertainty associated with rainfall intensity for equations of group2 is about $25 \%$ higher than Manning's roughness in Kasilian catchment, while in Amameh catchment the uncertainty caused by Manning's roughness coefficient is about 2 times of rainfall intensity.

As an overall view, one can deduce that the most effective parameters which contribute on the uncertainty of $T_{c}$ equations in humid regions are: rainfall intensity (i), Manning's roughness coefficient (n) and other land cover coefficients, flow path Length (L), the difference elevation between endpoint of main river $(\mathrm{H})$, flow path slope $\left(S_{c}\right.$ and $\left.S_{b}\right)$ and catchment Area (A), respectively. However, in dry and semi-arid regions, because of the low variations of rainfall intensity, Manning's roughness and other land cover coefficients are more sensitive and cause considerable uncertainty in estimating $T_{c}$ value.

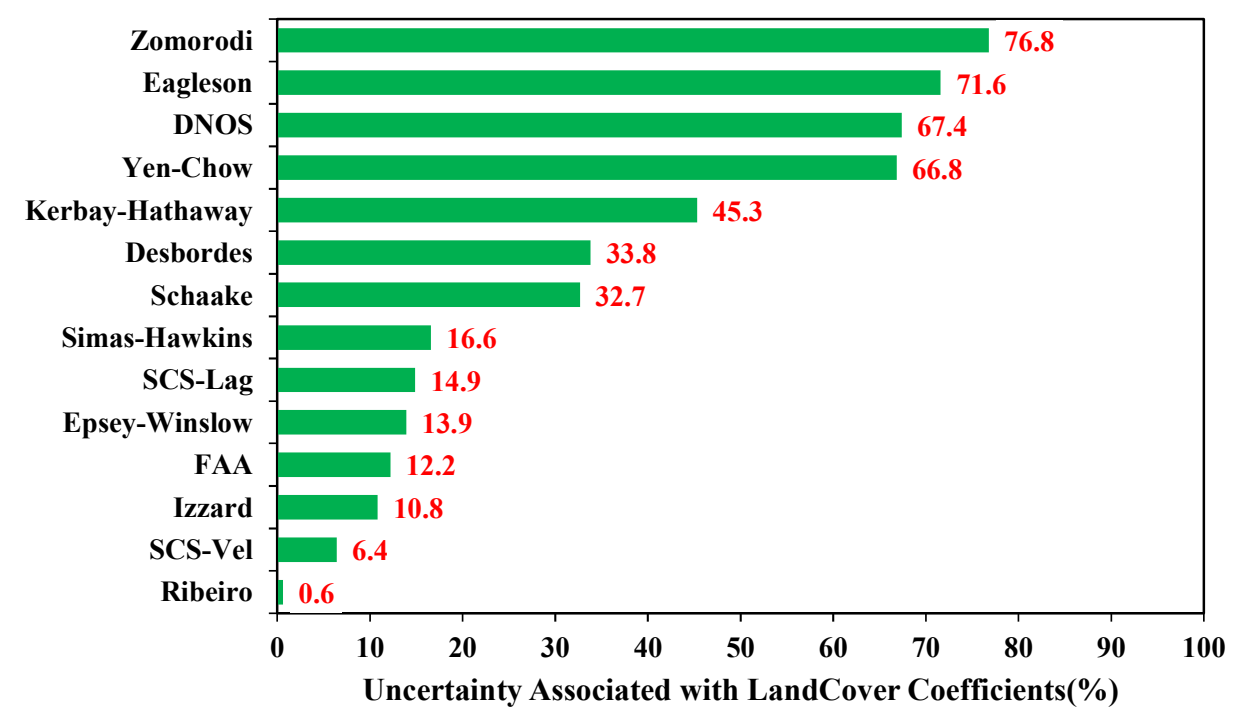

Fig. 12: Contribution of land cover coefficients on the output uncertainty 
Uncertainty Associated with Scale Effects (Data Resolution and DEM Resolution) and Streams Delineation Threshold

All of the $T_{c}$ equations depend on geomorphological characteristics and hence affected by scale effects and streams delineation threshold. The question brings up here is that " which of them makes more sensitivity and considerable uncertainty in estimating $T_{c}$ value? ". The results of the analysis demonstrated that in all $T_{c}$ equations which only depend on geomorphological parameters the uncertainty associated with streams delineation threshold, shown in Fig. 14, is about 3-6 times greater than other factors. Thus, the streams delineation threshold emerges to be the biggest contributor to the uncertainty when only the geomorphological parameters are considered. Hence, the value of this factor needs to be more considered with precision for accurate estimation of $T_{c}$ especially in ungauged catchments. Needless to say that in the first group's equations, because of the importance of rainfall attributes and land cover coefficients, the scale effects and other factors is not remarkable and could be ignored.

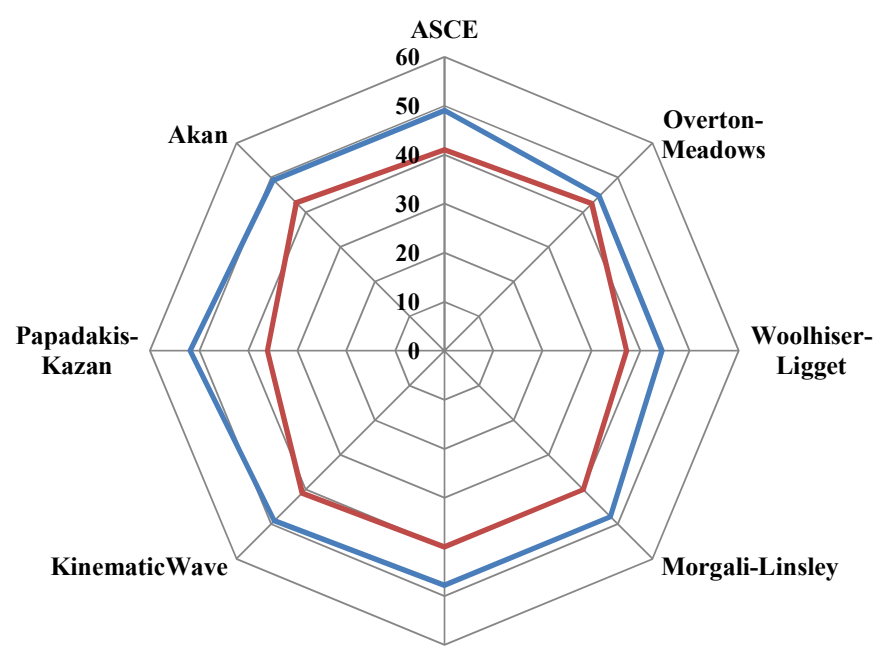

Rgan-Duru

_Rainfall_Intensity $\longrightarrow$ Manning_Roughness

(a)

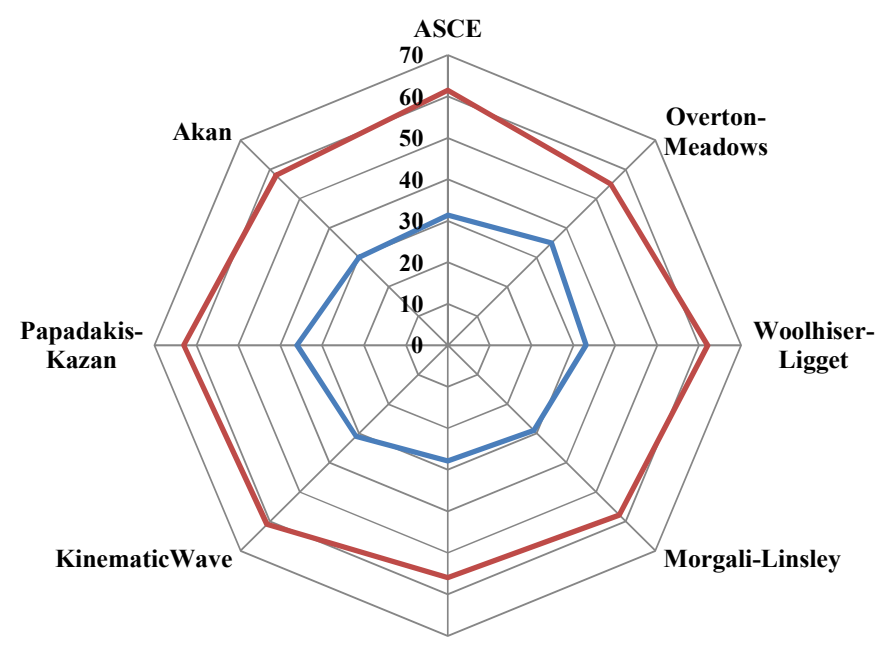

Rgan-Duru

_Rainfall_Intensity_Manning_Roughness

(b)

Fig. 13: Uncertainty associated with rainfall intensity and Manning's roughness coefficient (a) Kasilian Catchment (b) Amameh Catchment 


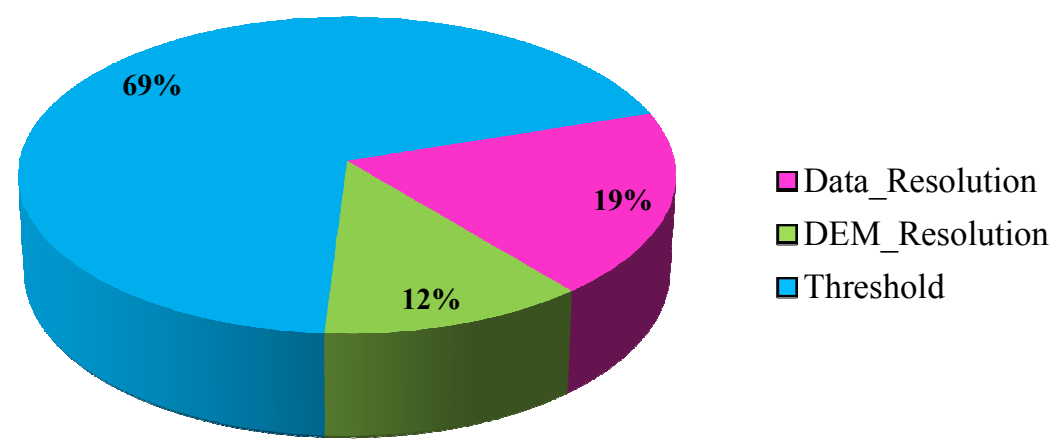

Fig. 14: Uncertainty associated with the scale effects and streams delineation threshold

\section{Conclusion}

The important issues focused on in this study are the assessment and uncertainty analysis of time of concentration $\left(T_{c}\right)$ equations, the uncertainty associated with different map scales and different inputs. Since uncertainty is considered to be a serious problem in hydrological model parameters and their impacts on the uncertainty of model simulations, this study investigates the factors that cause uncertainty on the estimation of $T_{c}$ values in Kasilian and Amameh catchments. The results of the analyses show that based on Coefficient of Variation $(\mathrm{CV})$, all $T_{c}$ equations could be categorized into two groups. The first group's equations due to depending on several inputs, such as rainfall attributes, watershed's characteristic and land cover related coefficients, result remarkable uncertainty and the minimum and maximum uncertainty of equations fall into this group is about 36.7 and $61.4 \%$, respectively. Compared to the first group, the uncertainty of second group's formulas is slightly low and the average and maximum $\mathrm{CV}$ value is about 16.5 and $28.4 \%$, respectively. The major factors causing uncertainty in the estimation of $T_{c}$ value are factors due to maps scale, which are used for extraction of watershed's parameters and land cover coefficients, DEM resolution, streams delineation threshold and rainfall attributes. Findings of this study indicate that the rainfall attributes play an important role in estimation of $T_{c}$ especially in humid region with a wide range of rainfall variations. But in dry and semi-dry regions the contribution of land cover-related coefficients on the uncertainty of $T_{c}$ equations is higher than rainfall attributes and other factors. This research also shows that, for equations are only based on geomorphological parameters, the uncertainty associated with streams delineation threshold is about 3-6 times of DEM resolution and map scale (data resolution). Needless to say that in the second group's equations, because of the importance of rainfall attributes and land cover coefficients, the effects of these factors is not remarkable and could be ignored. The results of this research can be used as an appropriate guidance for engineers and researchers who are looking for a best formula for estimation of
$T_{c}$ value, especially in ungauged watersheds. In addition, to reduce the confidence interval of estimated $T_{c}$, the parameters leading to greater uncertainty need to be estimated more accurately.

\section{Acknowledgment}

I thank IKIU University and anonymous reviewers for their useful comments.

\section{Ethics}

The present study was approved by IKIU University.

\section{References}

Akan, A.O. and R.J. Houghtalen, 2003. Urban hydrology, hydraulics and storm water quality: Engineering applications and computer modeling. 1st Edn., John Wiley and Sons, Hoboken, ISBN-10: 0471431583, pp: 373.

ADOT, 1993. Highway Drainage Design Manual Hydrology. 1st Edn., Arizona Department of Transportation, Phoenix.

ASDOT, 1995. Alaska Highway Drainage Manual.1st Edn., Alaska State Department of Transportation, Alaska.

Azizian, A. and A.R. Shokoohi, 2014. DEM resolution and stream delineation threshold effects on the results of geomorphologic-based rainfall runoff models. Turkish J. Eng. Env. Sci., 38: 64-78.

Azizian, A. and A.R. Shokoohi, 2015a. Effects of data resolution and stream delineation threshold effects on the results of a Kinematic Wave based GIUH model. J. Water S.A, 4: 61-70.

Azizian, A. and A.R. Shokoohi, 2015b. Investigation of the effects of DEM creation methods on the performance of a semi distributed model: TOPMODEL. J. Hydro. Eng.

Bastola, S., H. Ishidaira and K. Takeuchi, 2008. Regionalization of hydrological model parameters under parameter uncertainty: A case study involving TOPMODEL and basins across the globe. J. Hydrol., 357: 188-206. 
Bobba, A.G., V.P. Singh and L. Bengtsson, 1996. Application of first-order and monte carlo analysis in watershed water quality models. Water Resour. Manag., 10: 219-240.

CDH, 1960. California Culvert Practice. 2nd Edn., Calif. State Print. Office, Sacramento, pp: 119.

Carter, R.W., 1961. Magnitude and frequency of floods in suburban areas. US Geologi. Survey, Reston, VA.

Chen, Y., Y. Hsu, K.T. Kuo, 2013. Uncertainty in the methods flood discharge measurement. Water Resour. Manag., 27: 153-167.

Chow, V.T., 1964. Handbook of Applied Hydrology. 1st Edn., McGraw-Hill, New York.

Chow, V.T., D.R. Maidment and L.W. Mays, 1988. Applied Hydrology. 1st Edn., McGraw-Hill, New York.

Christiaens, K. and J. Feyen, 2000. The influence of different methods to derive soil hydraulic properties on the uncertainty of various model outputs of a distributed hydrological model. Phys. Chem. Earth Pt B, 25: 679-683.

de Almeida, I.K., A.K. Almeida, J.L. Steffen and S.T. Alves, 2016. Model for estimating the time of concentration in watersheds. Water Resources Manage., 30: 4083-4096.

Dooge, J.C.I., 1973. Linear Theory of Hydrologic Systems. 1st Edn., Agricultural Research Service.

Egelson, P.S., 1962. Unit hydrograph characteristics for sewered areas. j.hydr.Div, ASCE. 88 (HY2)

Eslamian, S. and A. Mehrabi, 2005. Determination of experimental relations in estimation of concentration time in mountainous watershed basins. J. Natural Resources Agric. Sci., 12: 23-34.

Fang, X., D.B. Thompson, T. Cleveland and P. Pradhan, 2007. Variations of time of concentration estimates using NRCS velocity method. J. Irrigation Drainage Eng., 133: 314-322. DOI: 10.1061/(ASCE)07339437(2007)133:4(314)

Fang, X., D.B. Thompson, T.G. Cleveland, P. Pradhan and R. Malla, 2008. Time of concentration estimated using watershed parameters determined by automated and manual methods. J. Irrigation Drainage Eng., 134: 202-211.

FAA, 1970. Advisory circular on airport drainage. US Federal Aviation Administration

Flavell, D.J., 1983. The rational method applied to small rural catchments in the south west of western Australia. Civ. Eng. Trans. Inst. Engrs. Aut., 25: 121-127.

Giandotti, M., 1934. Previsione delle piene e delle magre dei corsi d'acqua. Ministero LL.PP., Memorie e studi idrografici 8(2) Servizio Idrografico Italiano, Rome (in Italian)

Grison, F., M. Kobiyama and R. Da Silva, 2008. Conceptual investigation of time of concentration. From Headwaters Ocean.
Haktanir, T. and N. Sezen, 1990. Suitability of twoparameter gamma and three-parameter beta distributions as synthetic unit hydrographs in Anatolia. Hydrol. Sci. J., 35: 167-184.

Hancock, G.R., 2005. The use of digital elevation models in the identification and characterization of catchments over different grid scales. Hydrol. Proc., 45: 231-243.

Haan, C.T., Barfield, B.J., and Hayes, J.C. 1994. Design Hydrology and Sedimentology for Small Catchments. Elsevier, Amsterdam, Netherland.

Hathaway, G.A., 1945. Design of drainage facilities. Trans. Am. Soc. Civ. Eng., 110: 697-733.

Hotchkiss, R.H. and B.E. Mccallum, 1995. Peak discharge for small agricultural watersheds. J. Hydraulic Eng., 121: 36-47.

Hughes, D.A., E. Kapangaziwiri and T. Sawunyama, 2010. Hydrological model uncertainty assessment in southern Africa. J Hydrol., 378: 221-232.

Izzard, C.F., 1946. Hydraulics of runoff from developed surfaces. Proceedings of the 26th Annual Meetings of the Highway Research Board, National Research Council, (NRC' 46), Washington.

Johnstone, D. and W.P. Cross, 1949. Elements of Applied Hydrology. 1st Edn., Ronald Press, New York.

Kerby, W.S., 1959. Time of concentration for overland flow. Civ. Eng., 26: 60-60.

Kibler, D.F. and G. Aron, 1983. Evaluation of $T c$ methods for urban watersheds. Proceedings of the Conference on Frontiers in Hydraulic Engineering, (FHE' 83), New York, pp: 553-558.

Kirpich, Z.P., 1940. Time of concentration of small agricultural watersheds. Civil Eng., 10: 362-368.

Kosari, M.R., M.A. Saremi Nayeeni, M. Tazeh and F.M. Rahim, 2010. Sensitivity analysis of four concentration time estimation methods in watershed basins. J. Khoshkboom, 1: 43-55.

Linsley, R.K., M.A. Kohler, J.L. Paulhus, M.F. Serra and F.D. Aparicio, 1977. Hidrologia para ingenieros. McGraw-Hill, pp: 386.

Loucks, D.P., J.R. Stedinger, J.P.M. Dijkman and M.T. Villars, 2005. Water resources systems planing and mangement an introduction to methods, models and application. Unesco Publishing

Mata-Lima, H., H. Vargas, J. Carvalho, M. Gonçalves and H. Caetano et al., 2007. Comportamento hidrolgico de bacias hidrogrJficas:integraçৎo de métodos e aplicaçəo a um estudo de caso. Revista Escola de Minas.

Mays, L.W. and Y.K. Tung, 2002. Hydrosystems Engineering and Management. 1st Edn., Water Resources Publications, Highlands Ranch, ISBN-10: 1887201327, pp: 530.

McCuen, R., S. Wong and W. Rawls, 1984. Estimating urban time of concentration. J. Hydraulic Eng. Am. Society Civil Engineers, 110: 887-904.

McCuen, R.H., 2009. Uncertainty analyses of watershed time parameters. J. Hydraulic Eng., 14: 490-498. 
Mockus, V., 1961. Watershed lag. US Department of Agriculture, Soil Conservation Service, ES-1015, Washington, DC.

Morgali, J.R. and R.K. Linsley, 1965. Computer analysis of overland flow. J. Hydraulics Division, 91: 81-100.

NRCS, 1972. National engineering handbook. U.S. Department of Agriculture, Washington D.C National Resource Conservation Service.

NRCS, 1986. Urban hydrology for small watersheds. Technical Release 55, Washington, D.C National Resource Conservation Service.

Overton, D.E. and M.E. Meadows, 1976. Storm Water Modeling. 1st Edn., Academic Press, Inc. Ragan.

Papadakis, C. and N. Kazan, 1986. Time of concentration in small rural watersheds. Technical report 101/08/86/CEE. College of Engineering, University of Cincinnati, Cincinnati, $\mathrm{OH}$.

Povlovic, S.B. and Moglen, G.E. 2008. Discretization issues in travel time calculation. Journal of hydrologic engineering, 13(2): 71-79.

Pasini, F., 1914. Relazione sul progettodella bonifica renana. Bologna. Italy.

Pilgrim, D.H. and G.E. McDermott, 1982. Design floods for small rural catchments in eastern New South Wales. Civil Engg Trans Inst. Engrs Aust.

Pradahan, N.R., F.R. Ogden, Y. Tachikawa and K. Takara, 2008. Scaling of slope, upslope area and soil water deficit: Implications for transferability and regionalization in topographic index modeling. Water Resources Res., 44: 12-21.

Ragan, R.M. and J.O. Duru, 1972. Kinematic wave nomograph for times of concentration. J. Hydr. Div., 98: $1765-1771$.

Ribeiro, G., 1961. Acerca do calculo da vasəo de obras d'arte: Tempo de concentraç^o, Revista do Clube de Engenharia. 294: 16-19.

Salimi, E.T., A. Nohegar, A. Malekian, M. Hoseini and A. Holisaz, 2016. Estimating time of concentration in large watersheds. Paddy Water Environ., 4: 20-135.

Schaake, J.G., J.C. Geyer and J.W. Knapp, 1967. Experimental examination of the Rational Method. J. Hydraulics Division, 93: 353-370

Sharifi, S. and S.M. Hosseini, 2011. Methodology for identifying the best equations for estimating the time of concentration of watersheds in a particular Region. J. Irrigation Drainage Eng., 137: 712-719. DOI: 10.1061/(ASCE)IR.1943-4774.0000373

Sheridan, J., 1994. Hydrograph time parameters for flatland watersheds. Trans, ASAE, 37: 103-113. DOI: 10.13031/2013.28059)@1994

Silveira, A.L.L., 2005. Performance of time of concentration formulas for urban and rural basins. Brazilian J. Water Resources, 10: 5-23.
Singh, V.P., 1988. Hydrologic systems: Rainfallrunoff modeling, Volume 1, Prentice Hall Publication, pp: 960.

Simas, M.J. and R.H. Hawkins, 2002. Lag time characteristics for small watersheds in the U.S. Proceedings of the 2nd Federal Interagency Hydrologic Modeling Conference, (HMC' 02), Las Vegas.

Tarboton, D.G., 1991. On the extraction of channel networks from digital elevation data. Hydrological Processes, 5: 81-100.

Temez, J.R., 1978. Calculo hidrometeorologico de caudales maximos em pequeas cuencas naturales. Madrid: Ministério de Obras Publicasy Urbanismo (MOPU). Direccion General de Carreteras.

Tung, Y.K. and L.W. Mays, 1981. Risk models for flood levee design. Water Resour. Res., 17: 833-841.

USWRC, 1981. Estimating Peak Flow Frequencies for Natural Ungaged Watersheds: A Proposed Nationwide Test. 1st Edn., U.S. Water Resources Council, Washington, pp: 346

Van Sickle, D., 1962. The effects of urban development on storm runoff. Texas Engineer, 32: 23-27.

Williams, G.B., 1922. Flood discharges and the dimensions of spillways in India. Eng. (London) 134: 321-321.

Wolock, D.M. and C.V. Price, 1994. Effects of digital elevation model map scale and data resolution on a topography-based watershed model. Water Resources Res., 30: 3041-3052.

Wong, T., 2009. Evolution of kinematic wave time of concentration formulas for overland flow. J. Hydrol. Eng., J. Am. Society Civil Engineers, 14: 739-744.

Wong, T.S.W. and F. Asce, 2005. Assessment of time of concentration formulas for overland flow. J. Irrigation Drainage Eng., 131: 383-387.

Woolhiser, D.A. and J.A. Liggett, 1967. Unsteady onedimensional flow over a plane the rising hydrograph. Water Resour. Res., 3: 753-771.

Yen, B.C. and V.T. Chow, 1983. Local design storms. U.S. Dept. of Transportation, Federal Highway Administration, Washington, D.C.

Zhang, Z.H., L.U. Wenxi, C.H.U. Haibo, C.H. Weiguo and Z.H. Ying, 2014. Uncertainty analysis of hydrological model parameters based on the bootstrap method: A case study of the SWAT model applied to the Dongliao River Watershed, Jilin Province, Northeastern China. Sci. China Tech. Sci., 57: 219-229.

Zomorodi, K., 2005. Revising the NRCS sheet flow travel time equation for. Water Resources, 336: 1-4. 